\title{
Improve Learning Motivation Through the Media Ppwer Point In Primary School
}

\author{
Tarjono \\ SD Negeri 2 Kemawi \\ Tarjonomas85@gmail.com
}

\section{Article History}

accepted 14/11/2020

approved 21/11/2020

published 26/11/2020

\begin{abstract}
This study aims to increase the learning motivation of students in Theme 4 Cleanliness and health of Class 2 environment through PPT media for class II SD Negeri 2 Kemawi, totaling 14 students consisting of 4 boys and 10 girls. The data collection technique is a written test. The results showed that through the PPT media, learning outcomes in Theme 4 of Cleanliness and Health in SD Negeri 2 Kemawi could be improved. From the average value in the initial condition which is only 64 at the end of cycle I to 72, at the end of cycle II to 78 and at the end of cycle III to 85 . The results of this study indicate that the improvement of learning outcomes Theme 4 Cleanliness and environmental health Class 2 can be successful by using PPT media in grade II SD Negeri 2 Kemawi. Starting from this research, it is suggested that: 1) Elementary school teachers in teaching using PPT media need to increase their effectiveness and creativity, 2) Teachers who feel pessimistic in learning Theme 4 Cleanliness and environmental health Class 2 should attend training at the PKG, KKG and Workshop.
\end{abstract}

Keywords: Motivation, Power Point, elementary school

\begin{abstract}
Abstrak
Penelitian ini bertujuan untuk meningkatkan Motivasi belajar peserta didik Tema 4 Kebersihan dan kesehatan lingkungkan Kelas 2 melalui media PPT bagi siswa kelas II SD Negeri 2 Kemawi yang berjumlah 14 peserta didik yang terdiri dari 4 laki-laki dan 10 perempuan. Teknik pengumpulan data adalah tes tertulis. Hasil penelitian menunjukkan bahwa melalui media PPT, hasil belajar Tema 4 Kebersihan dan kesehatan lingkungkan Sekolah SD Negeri 2 Kemawi dapat ditingkatkan. Dari rata-rata nilai pada kondisi awal yang hanya 64 di akhir siklus I menjadi 72, di akhir siklus II menjadi 78 dan di akhir siklus III menjadi 85. Hasil penelitian ini menunjukkan bahwa peningkatan hasil belajar Tema 4 Kebersihan dan kesehatan lingkungkan Kelas 2 dapat berhasil dengan menggunakan media PPT di kelas II SD Negeri 2 Kemawi. Bertolak dari penelitian ini, maka disarankan : 1) Guru Sekolah Dasar dalam mengajarkan menggunakan Media PPT perlu ditingkatkan efektifitas dan kreatifitasnya, 2) Guru yang merasa pesimis dalam pembelajaran Tema 4 Kebersihan dan kesehatan lingkungkan Kelas 2 sebaiknya mengikuti pelatihan pada forum pertemuan PKG,KKG dan Wrokshop.

Kata kunci: Motivasi, Power Point ,sekolah dasar

Social, Humanities, and Education Studies (SHEs): Conference Series https://jurnal.uns.ac.id/shes

p-ISSN 2620-

9284

e-ISSN 2620-

9292
\end{abstract}




\section{PENDAHULUAN}

Pendidikan merupakan suatu hal terpenting dalam kehidupan seseorang, karena melalui pendidikan, seseorang dipandang terhormat, memiliki karir yang baik serta dapat bertingkah sesuai norma-norma yang berlaku (Zaroha1, Firman, \& Desyandri, 2016).Sekolah Dasar (SD) adalah jenjang paling dasar pada pendidikan formal di Indonesia. Tugas utamanya adalah mempersiapkan peserta didik dengan memperkenalkan berbagai pendidikan dasar baik aspek pengetahuan, aspek keterampilan, aspek sikap, dan perilaku. Kegiatan pembelajaran Sekolah Dasar (SD) pata tahun 2018 menerapkan kurikulum 2013 yang berbasis karakter dan kompetensi yang mewajibkan anak untuk aktif dalam pembelajaran

Hasil pengamtan saya di dalam kelas II di SDN 2 Kemawi ,diketahui bahwa pada saat guru menjelaskan pada materi tema Hidup bersih dan Sehat dilingkuan sekolah Peserta Didik kurang respon dan tidak termotivasi terhadap pembelajaran yang dilakukan oleh guru. Perilaku Peserta Didik yang tidak sesuai dengan harapan proses pembelajaran, seperti ribut didalam kelas sehingga saat ada tugas yang diberikan oleh guru Peserta Didik cenderung tidak mampu mengerjakannya (Handayani \& Sriwati, 2014). Hal tersebut dikarenakan proses pembelajaran dilaksanakan dengan teori dan nasehat saja dan tampa melibatkan Peserta Didik dalam proses pembelajaran. Hal ini membuat pemahaman Peserta Didik terhadap pembelajaran berkurang dan pemahaman konsep terhadap materipun tidak mereka peroleh.

Faktor di atas apabila tidak segera di atasi, maka akan menimbulkan dampak negatif. Dampak yang dapat timbul adalah peserta didik tidak memiliki keterampilan menyelesaikan masalah dan kurang bersemangat dalam pembelajaran. Faktanya keterampilan pemecahan masalah penting untuk dikuasai peserta didik karena keterampilan tersebut sangat berperan dalam pemecahan masalah yang dihadapi peserta didik dalam kehidupan sehari hari. Dalam kondisi tersebut, peserta didik akan kesulitan dalam memutuskan langkah-langkah atau solusi ketika dihadapkan pada masalah sehingga hasil belajar peserta didik menjadi tidak maksimal.

Dengan adanya hal tersebut menjadikan bahan pemikiran guru untuk dapat menemukan model yang tepat dalam mengenalkan dan menerapkan arti hidup sehat bagi peserta didik. Model yang praktis dalam memotivasi peserta didik dalam menjaga hidup bersih dan hidup sehat di sekolah adalah mengunakan media pembelajaran yang menarik yaitu dengan media Power Poin dalam menyapekan materi, Peserta Didik akan melihat dan belajar lebih tetarik Tingkat keberhasilan pembelajaran tidak telepas dari peranan orang tua dan kelurga yang ada di lingkungan peserta didik tersebut, namun disisilain sebagian besar orang tua peserta didik SD Negeri 2 Kemawi kurang menyadari peranan orang tua ketika anaknya berada di rumah, mereka meyakini bahawa pendidikan anaknya mutlak didapat di sekolah. Setelah peneliti menyimpulakan penyebabnya $99 \%$ ternyata orang tua sisiwa adalah petani yang sebagian waktu kegiatannya berada di kebun/hutan, Dari kesimpulan di atas peneliti mengakat permasalahan yang ada di SD Negeri 2 Kemawi, yaitu pembelajaran Tema 4 Kebersihan dan kesehatan lingkungkan Kelas 2 semster 1 (satu). Pembelajaran Tema 4 Kebersihan dan kesehatan lingkungkan Kelas 2 sebelumya dilaksanakan dengan menggunakan metode ceramah dan membaca buku sediri di rumah.

\section{METODE}

Penelitian ini adalah penelitian tindakan kelas (Classroom Action Research) dengan menerapkan metode diskusi. mengacu pada model Kemmis \& Taggart (dalam Trianto, 2010: 30) yang terdiri dari empat komponen yaitu: (1) perencanaan (planning), (2) tindakan (acting), (3) pengamatan (observing), dan (4) refleksi (reflecting). Pada model ini, komponen tindakan dan pengamatan dilaksanakan pada waktu yang sama. 
Analisis penelitian ini adalah analisis deskriptif kuantitafif kualitatif dimana dalam penelitian ini selain penyajian hasil berupa data maupun angka peneliti juga menentukan bagaimana cara pengolahan hasil penelitian yakni dengan membuat analisisnya dengan menerapkan Media PPT. Penelitian ini dilaksanakan pada peserta didik kelas II SD Negeri 2 Kemawi Tahun Pelajaran 2020/2021 sebanyak 2 sklus secara Daring dengan satu kali pertemuan diisetiap siklusnya. Siklus I dilaksanakan pada tanggal 5 November 2020. Siklus II dilaksanakan pada tanggal 17 November 2020. Teknik pengumpulan data yang dilakukan dengan observasi dan tes. Observasi meliputi observasi keterlaksanaan metode diskusi, sikap peserta didik dan motivasi. Untuk hasil belajar menggunakan tes formatif.

\section{HASIL DAN PEMBAHASAN}

Pada pelaksanan pembelajaran yang telah di laksanakan oleh guru SD Negeri 2 Kemawi pada tema kebersihan dan kesehatan lingkungan di sekolah. Disimpulkan bahwa pembelajaran yang sudah berlangsung masih belum tuntas kususnya pada materi tersebut, sebagi bukti peneliti mengabil hasil tes formati pada study awal dengan hasil sebagai berikut :

Sebelum peneliti melaksankan pembelajaran pada siklus I peneliti mengambil data hasil pembelajaran awal, sebagai bahan untuk melihat hasil peningkatan belajar pada tahap siklus I. setelah pembelajaran pada tahap siklus I selesai didapat hasil sebagai berikut ;

Tabel 1. Rekap hasil tes formatif setudi awal siklus I

\begin{tabular}{cccccc}
\hline No & Nilai & $\begin{array}{c}\text { Studi Awal } \\
\text { Jumlah }\end{array}$ & $\begin{array}{c}\text { Siklus I } \\
\text { Jumlah }\end{array}$ & Prosentase & $\begin{array}{c}\text { Tuntas/Tidak } \\
\text { Tuntas }\end{array}$ \\
\hline 1 & $90-100$ & & 1 & $7 \%$ & Tuntas \\
\hline 2 & $80-89$ & 1 & 1 & $7 \%$ & Tuntas \\
\hline 3 & $70-79$ & 3 & 6 & $43 \%$ & Tuntas \\
\hline 4 & $60-69$ & 4 & 4 & $28 \%$ & Tidak Tuntas \\
\hline 5 & $50-59$ & 4 & 2 & $14 \%$ & Tidak Tuntas \\
\hline 6 & $40-49$ & 2 & - & & - \\
\hline & Jumlah & 14 & 14 & & \\
\hline
\end{tabular}

Dari tabel 4.1 di peroleh keterangan sebagai berikut: Pada kondisi awal yang tuntas belajar hanya 4 dari 14 peserta didik sedangkan pada siklus I meningkat menjadi 8 anak atau sama dengan $57 \%$. Pada kondisi awal yang tidak tuntas sebanyak 8 peserta didik, atau sama dengan $43 \%$ sedangkan pada siklus I menurun menjadi 6 peserta didik atau sama dengan $41 \%$. 
Tabel 2 Rekapitulasi Ketuntasan dan tidak tuntas pada Study awal dan Siklus I

\begin{tabular}{cccc}
\hline $\begin{array}{c}\text { Kegitan } \\
\text { Pembelajaran }\end{array}$ & $\begin{array}{c}\text { Jumlah Peserta } \\
\text { Didik Tuntas }\end{array}$ & $\begin{array}{c}\text { Jumlah Peserta } \\
\text { Didik Tidak Tuntas }\end{array}$ & $\begin{array}{c}\text { Presentase } \\
\text { kenaikan. }\end{array}$ \\
\hline Study Awal & $42 \%$ & $58 \%$ & - \\
\hline Siklus I & $63 \%$ & $37 \%$ & $21 \%$ \\
\hline
\end{tabular}

Berdasarkan tabel 4.2 di atas. Peserta didik mengalami peningkatan hasil pembelajaran pada tahap siklus I sebesar $21 \%$. Dari tabel 4.2 diperoleh data bahwa, peserta didik lebih aktif dalam mengikuti pembelajaran pada siklus I di banding dengan data Sudy awal.

Tabel 3 Rekapitulasi Ketuntasan dan tidak tuntas pada Study awal dan Siklus II

\begin{tabular}{clcc}
\hline No & Pembelajaran & $\begin{array}{c}\text { Peserta didik yang Aktif Dalam Mengikuti } \\
\text { Pembelajaran }\end{array}$ & Persentase \\
\hline 1 & Studi Awal & 6 & $46 \%$ \\
\hline 2 & Siklus I & 10 & $75 \%$ \\
\hline 3 & Siklus II & 12 & $96 \%$
\end{tabular}

Dari tabel 3 diperoleh data bahwa, peserta didik lebih meningkat aktif dalam mengikuti pembelajaran pada siklus II di banding dengan data pembelajaran sebelumnya.

Tabel 4 rekapitulasi ketuntasan dan tidak tuntas

\begin{tabular}{lccc}
\hline $\begin{array}{c}\text { Kegitan } \\
\text { Pembelajaran }\end{array}$ & $\begin{array}{c}\text { Jumlah Peserta } \\
\text { Didik Tuntas }\end{array}$ & $\begin{array}{c}\text { Jumlah Peserta } \\
\text { Didik Tidak Tuntas }\end{array}$ & $\begin{array}{c}\text { Presentase } \\
\text { kenaikan. }\end{array}$ \\
\hline Study Awal & $42 \%$ & $58 \%$ & - \\
\hline Siklus I & $63 \%$ & $37 \%$ & $21 \%$ \\
\hline Siklus II & $96 \%$ & $4 \%$ & $33 \%$ \\
\hline
\end{tabular}

Berdasarkan tabel di atas. Peserta didik mengalami peningkatan hasil pembelajaran pada tahap siklus I sebesar $21 \%$. Hasil analisis pada study awal untuk tes formatif sangat rendah, dari jumlah peserta didik 14 yang tuntas hanya 4 siswa 28 $\%$ nilainya diatas KKM 70 sementara yang tidak tuntas 10 siwa $71 \%$ nilai dibawah KKM. 1 Penguasaan peserta didik terhadap materi pada siklus I sudah mulai meningkat. Dimana pada studi awal jumlah peserta didik yang tuntas hanya 4 dari 14 peserta didik, pada siklus 1 meningkat menjadi 8 dari 14 peserta didik. 2 Pada siklus II keadaan ini juga menujukan perubahan yang sangat berarti , yaitu jumlah peserta didik yang tuntas belajarnya mencapai 13 anak. Keterlibatan anak dalam proses pembelajaran dari siklus awal hingga siklus 2 juga terus mengalami peningkatan.

Brown (1973) mengungkapkan bahwa media pembelajaran yang digunakan dalam kegiatan pembelajaran dapat mempengaruhi terhadap efektivitas pembelajaran. Pada mulanya, media pembelajaran hanya berfungsi sebagai alat bantu guru untuk mengajar yang digunakan adalah alat bantu visual. Sekitar pertengahan abad $\mathrm{Ke}-20$ usaha pemanfaatan visual dilengkapi dengan digunakannya alat audio, sehingga lahirlah alat bantu audio-visual. Sejalan dengan perkembangan ilmu pengetahuan dan teknologi (IPTEK), khususnya dalam bidang pendidikan, saat ini penggunaan alat 
bantu atau media pembelajaran menjadi semakin luas dan interaktif, seperti adanya komputer dan internet.

Berdasarkan kedua siklus perbaikan pembelajaran yang dilaksanakan ternyata mengalami peningkatan yang sangat berarti. Apabila kita lihat dari grafik kemajuan ketuntasan hasil belajar dari awal siklus hingga siklus 2 mengalami kemajuan yang cukup tinggi yaitu sekitar $50 \%$. Pengunaan media PPT sangat menguntukan bagi peserta didik dan pendidik diantaranya lebih hemat dari segi biaya dan waktu, pemebelajaran menjadi lebih menarik.

\section{SIMPULAN}

Peneliti menyimpulkan bahwa berdasarkan hasil yang diperoleh selama proses perbaikan pembelajaran berlangsung, hasil penelitian perbaikan pembelajaran dari siklus I dan siklus II rata-rata nilai peserta didik selalu meningkat, sebagai contoh nilai murid yang bernama Nofiki dari yang semula 55 menjadi 65 pada siklus I dan 75 pada siklus II. Peserta didik yang nilainya mencapai KKM hingga 23 dari 24 peserta didik atau $96 \%$, meskipun ada satu anak yang tidak tuntas hal itu disebabkan karna ada kelainan pada anak tersebut. Dengan melihat hasil akhir dari nilai peserta didik yang mengalami banyak peningkatan, maka pendidik menarik kesimpulan sebagai berikut: 1. Berdasarkan hasil perumusan masalah dapat diketahui bahwa melalui media PPT dapat meningkatkan hasil belajar Tema 4 Kebersihan dan kesehatan lingkungkan Kelas 2 tentang sejarah bagi peserta didik kelas II SD Negeri 2 Kemawi. 2 Penggunaan media PPT dapat lebih memotivasi peserta didik dalam proses pembelajaran Tema 4 Kebersihan dan kesehatan lingkungkan Kelas 2 materi sejarah. 3. Penggunaan media PPT mampu meningkatkan hasil belajar peserta didik,ini terlihat dari hasil belajar yang diperoleh peserta didik setelah siklus II mencapai rata - rata 80 dengan ketuntasan belajar mencapai $96 \%$.

Dari uraian di atas, peneliti menyimpulkan bahwa Penggunaan media PPT mampu memotivasi Peserta didik dalam proses pembelajaran tentang sejarah peninggalan pada masa hindu,budha dan islam di Indonesia dan juga Penggunaan media PPT dapat meningkatkan hasil belajar peserta didik, hal ini terbukti dari motivasi dan hasil belajar peserta didik yang meningkat. Sehingga berdasarkan hipotesis yang peneliti ajukan di atas telah terbukti dan dapat di terima.

\section{DAFTAR PUSTAKA}

Agus, Riyanto. Penelitian yang Relevan 2012/2013. Diunduh 4 Desember 2020 (http://.www.m-edukasi.web.id.)

Arikunto (2010). Alur Penelitian Tindakan Kelas. Diunduh 4 Desember 2020 (http://nurrynuryany69.blogspot.com/2013/01/tugas-ptk_5.html)

Gerlach Vernon S. \& Donal P. Ely. (2013). Pengertian Belajar. Diunduh 24 Desember 2020

(dikutip dari .blogspot.com/2013/03/pengertian-belajar-pengertian.html).

Hamalik, Oemar. (2003). Diunduh 4 Desember 2020. (http://belajarpsikologi.com/pengertian-motivasi-belajar/)

Masykur, dkk Ali, dkk. (2018). Hidup bersih dan Sehat. Surakarta: Kurikulum 2013 revisi. 2018

Mulyono. (2011).. Diunduh 4 Desember 2020 (http://ekalusmey.blogspot.com/2011/12/5-pandangan-ips-menurut-paraahli.html )

National Education Associaton. (1969). Media Pembelajaran. 4 Desember 2020 (http://belajarpsikologi.com/pengertian-media-pembelajaran/)

Ulihbukit. (1997). Suatu Pengantar ke dalam Metodologi Pengajaran. Salatiga: C.V Saudara 